\title{
Molecular and functional evaluation of a novel HIF inhibitor, benzopyranyl 1,2,3-triazole compound
}

\author{
Kyunghye Park ${ }^{1}$, Hye Eun Lee ${ }^{1}$, Sun Hee Lee ${ }^{1}$, Doohyun Lee $^{2}$, Taeho Lee ${ }^{2}$, You \\ Mie Lee L,2 $^{1,2}$ \\ ${ }^{1}$ BK21 Plus KNU Multi-Omics based Creative Drug Research Team, National Basic Research Laboratory of Vascular Homeostasis \\ Regulation, Kyungpook National University, Buk-gu, 702-701, Daegu, Republic of Korea \\ ${ }^{2}$ College of Pharmacy, Research Institute of Pharmaceutical Sciences, Kyungpook National University, Buk-gu, 702-701, \\ Daegu, Republic of Korea
}

Correspondence to: You Mie Lee, email: lym@knu.ac.kr

Keywords: HIF-1a inhibitor, chemical library, benzopyranyl 1,2,3-triazole

Received: September 27, $2016 \quad$ Accepted: December 01, 2016

Published: December 15, 2016

\section{ABSTRACT}

Hypoxia occurs in a variety of pathological events, including the formation of solid tumors. Hypoxia-inducible factor (HIF)-1a is stabilized under hypoxic conditions and is a key molecule in tumor growth and angiogenesis. Seeking to develop novel cancer therapeutics, we investigated small molecules from our in-house chemical libraries to target HIF-1a. We employed a dual-luciferase assay that uses a luciferase (Luc) reporter vector harboring five copies of hypoxia-responsive element (HRE) in the promoter. Under hypoxic conditions that increased Luc reporter activity by fourfold, we screened 144 different compounds, nine of which showed 30-50\% inhibition of hypoxia-induced Luc reporter activity. Among these, "Compound 12, a benzopyranyl 1,2,3-triazole" was the most efficient at inhibiting the expression of HIF-1a under hypoxic conditions, reducing its expression by $\mathbf{8 0} \%$. Under hypoxic conditions, the half

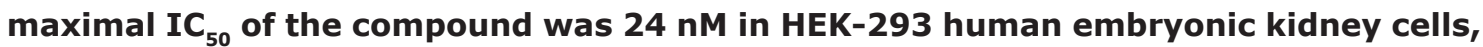
and $2 \mathrm{nM}$ in A549 human lung carcinoma cells. Under hypoxic conditions, Compound 12 increased hydroxylated HIF-1a levels and HIF-1a ubiquitination, and also dosedependently decreased HIF-1a target gene expression as well as vascular endothelial growth factor (VEGF) secretion. Furthermore, this compound inhibited VEGF-induced in vitro angiogenesis in human umbilical vein endothelial cells (HUVECs), and in vivo, it inhibited chick chorioallantoic membrane angiogenesis. In allogaft assays, cotreatment with Compound $\mathbf{1 2}$ and gefitinib significantly inhibited tumor growth and angiogenesis. Compound 12 can be a novel inhibitor of HIF-1a by accelerating its degradation, and shows much potential as an anti-cancer agent through its ability to suppress tumor growth and angiogenesis.

\section{INTRODUCTION}

Hypoxia is defined as a condition of lower $\mathrm{O}_{2}$, usually $\leq 2 \% \mathrm{O}_{2}$, while anoxia (severe hypoxia) is defined as a condition of $\leq 0.02 \% \mathrm{O}_{2}$. Most mammalian tissues experience $2-9 \% \mathrm{O}_{2}$ (on average, a partial pressure of $40 \mathrm{~mm} \mathrm{Hg}$ ), and ambient air is $21 \% \mathrm{O}_{2}$ (a partial pressure of $150 \mathrm{~mm} \mathrm{Hg}$ ). Hypoxia occurs in a variety of pathological events such as in arthritic joints, stroke, inflammation, tissue ischemia, and the growth of solid tumors. Under these circumstances, hypoxic cells generate energy through glycolysis to minimize oxygen consumption, and they activate signaling pathways that mediate cell growth, angiogenesis, and anti-apoptosis to improve cell survival [1-3]. Solid tumors contain hypoxic regions due to rapid cell proliferation, and hypoxia is a strong stimulator of tumor angiogenesis [4]. Hypoxia research has provided considerable information on the molecular mechanisms by which $\mathrm{O}_{2}$ levels influence the properties and behaviors of tumors, including altered cellular metabolism, proliferation, and angiogenesis, as well as increased resistance to chemotherapy and radiation $[1,5]$.

Hypoxia-inducible factors (HIFs) are well known as master regulators of $\mathrm{O}_{2}$ homeostasis, and they mediate 
many transcriptional changes in response to low $\mathrm{O}_{2}$ tension [6]. HIF-1 is expressed by all extant metazoan organisms. HIF-1 consists of an $\mathrm{O}_{2}$-sensitive $\alpha$ subunit and a constitutively expressed $\beta$ subunit [7]. HIF- $1 \alpha$ is constantly synthesized, but under normoxic conditions, it is rapidly degraded. Prolyl hydroxylase domain enzymes (PHDs) hydroxylate two proline residues (402 and/or 564) within the $\mathrm{O}_{2}$-dependent degradation (ODD) domain of HIF-1 $\alpha$. Subsequently, HIF-1 $\alpha$ binds to the von HippelLindau tumor suppressor protein (pVHL) and recruits an E3 ubiquitin ligase, resulting in HIF-1 $\alpha$ ubiquitination and proteasomal degradation $[7,8]$. Under hypoxic conditions, however, PHD activity is attenuated, leading to HIF-1 $\alpha$ protein stabilization. Stabilized HIF-1 $\alpha$ dimerizes with HIF- $1 \beta$ and translocate into the nucleus. The HIF- $1 \alpha / \beta$ heterodimer binds to hypoxia response elements (HREs) of target gene promoters, and consequently activates the transcription of downstream genes involved in angiogenesis, metastasis, apoptosis, and glycolysis [9-11].

Increased HIF-1 activity could result in increased cell survival or angiogenesis during hypoxia. However, decreased HIF-1 activity could inhibit cell survival or reduce the angiogenic activity of hypoxic regions such as those found in solid tumors. For these reasons, HIF-1 could be an important drug target for several diseases such as cancer, stroke, and heart disease, in which hypoxia is a central aspect [12]. In the process of adapting to a hypoxic environment, tumor cells promote the transcription of genes associated with angiogenesis, metabolism, cell proliferation, survival, $\mathrm{pH}$ regulation, and cell migration. Many of these genes are regulated by HIF- $1 \alpha$; therefore, HIF- $1 \alpha$ has emerged as an attractive target for the development of novel cancer therapeutics [13, 14]. For this reason, we screened small molecules to find potent HIF- $1 \alpha$ inhibitors, using reporter gene assays. We found that the candidate with the strongest HIF-1 $\alpha$-inhibiting activity was a benzopyranyl 1,2,3-triazole compound, so we examined its biological activities. We determined that its inhibitory effect is achieved via increasing HIF$1 \alpha$ degradation by ubiquitination. We then confirmed this benzopyranyl 1,2,3-triazole compound's effects on angiogenesis and tumor progression in vivo, at the molecular as well as the histological level.

\section{RESULTS}

\section{Selection of candidate HIF-1 $\alpha$ inhibitors from in-house chemical library via HRE reporter assay}

Because HIF- $1 \alpha$ is an attractive target for the development of cancer therapeutics, we screened small molecules to find HIF-1 $\alpha$ inhibitors. To test cellular toxicity, we performed MTT assays at various concentrations $(0.5-5 \mu \mathrm{M})$ of the 144 compounds (3-146). Compound 22 was too toxic at every dose, so we excluded Compound 22 from further study. Some Compounds such as 51,53 , and 58 showed cell toxicity at the highest dose $(5 \mu \mathrm{M})$ (Supplementary Figure S1), so we omitted this concentration from further investigation.

To identify active inhibitors of HIF-1 $\alpha$, a cell-based reporter assay was performed. HEK-293 cells were cotransfected with pGL3-5xHRE-Luc plasmid harboring five copies of hypoxia responsive element (HRE) from the VEGF gene promoter, and with pRL-SV40 encoding Renilla genes. The HRE-containing promoter of the HIF-1 target genes is regulated by HIF-1 activation. Transfected cells were treated with chemical compounds at $1 \mu \mathrm{M}$ and were exposed to hypoxic conditions $\left(1 \% \mathrm{O}_{2}\right)$ for $24 \mathrm{~h}$, and then were assayed. Echinomycin (E), a well-known HIF$1 \alpha$ inhibitor, was used as a positive control. Compared to normoxic control conditions, hypoxia increased this luciferase reporter's activity by approximately three-fold. Among the Compounds tested, nine $(12,45,54,94,101$, $103,105,127$ and 138) showed effects of significantly decreasing reporter activity (30-50\% inhibition compared to hypoxic control) (Figure 1) and were selected for further investigation.

\section{Compound 12 is selected as the most potent inhibitor of $\mathrm{HIF}-1 \alpha$ protein expression in the screened chemical library}

Next, we evaluated the inhibitory effects of the nine aforementioned test compounds on HIF- $1 \alpha$ protein accumulation by western blot analyses in A549 cells experiencing hypoxic conditions. A549 cells were treated with $1 \mu \mathrm{M}$ of each compound for $16 \mathrm{~h}$ at hypoxic conditions, and all nine compounds were found to significantly downregulate HIF-1 $\alpha$ expression. In particular, Compounds 12 and 45 showed the most potent inhibitory effect on HIF-1 $\alpha$ accumulation (Figure 2); however, because the inhibitory effects of Compound 45 in the reporter assay were less than those of Compound 12 (Figure 1), we chose Compound 12 for further study.

As shown in Figure 3A, the chemical structure of Compound 12 shows that it is a benzopyranyl 1,2,3-triazole. This compound was synthesized by $\mathrm{Cu}(\mathrm{I})$-catalyzed $[3+2]$ cycloaddition of 2-(azidomethyl)-2-methyl-6nitro-2 $\mathrm{H}$-chromene and 1-ethynyl-4-methoxybenzene $[15,16]$. Compound 12 has a benzopyran scaffold structure that is novel when compared to the chemical structures of known HIF-1 $\alpha$ inhibitors, such as YC-1 [3-(5'-hydroxymethyl-2'-furyl)-1-benzyl indazole] [17], topotecan (S)-10-[(dimethylamino)methyl]-4-ethyl-4,9dihydroxy-1 $H$-pyrano $\left[3^{\prime}, 4^{\prime}: 6,7\right]$ indolizino[1,2-b]quinoline3,14(4H,12H)-dione monohydrochloride [18], echinomycin [19], and manassantin [20]. Based on our results (shown in Figures 1 and 2) and the known chemical structures (Supplementary Figure S2) of the compounds we tested in Figure 2, we can speculate why Compound 12 behaves uniquely among the 145 compounds of our chemical library. We hypothesize that its activity is due to both the 
6-nitro-benzopyran and the 1,4-disubstituted 1,2,3-triazole moiety - because, among the compounds shown in Figure 2 as having an inhibitory activity on HIF-1 $\alpha$ expression, Compounds 12, 54, and 138 were 6-nitro-benzopyran derivatives, and Compounds 12, 94, 101, 103, and 105 have the 1,4-disubstituted 1,2,3-triazole moiety (Supplementary Figure S2).

At $1 \mu \mathrm{M}$ concentration, Compound 12 suppressed HIF-1 $\alpha$ transactivation activity by $50 \%$, and HIF- $1 \alpha$ protein levels by $80 \%$, when compared to the hypoxic control group (Figures 1 and 2). Therefore, we decided to test Compound 12 at concentrations lower than $1 \mu \mathrm{M}$, to determine the minimum effective concentration needed to achieve inhibition of HIF-1 $\alpha$. HEK-293 cells and A549 cells were treated with Compound 12, at 0.1-1000 nM concentrations, under hypoxic conditions for $16 \mathrm{~h}$. Surprisingly, even at $1 \mathrm{nM}$ concentration, Compound 12 downregulated HIF-1 $\alpha$ protein expression by approx. $30 \%$ in
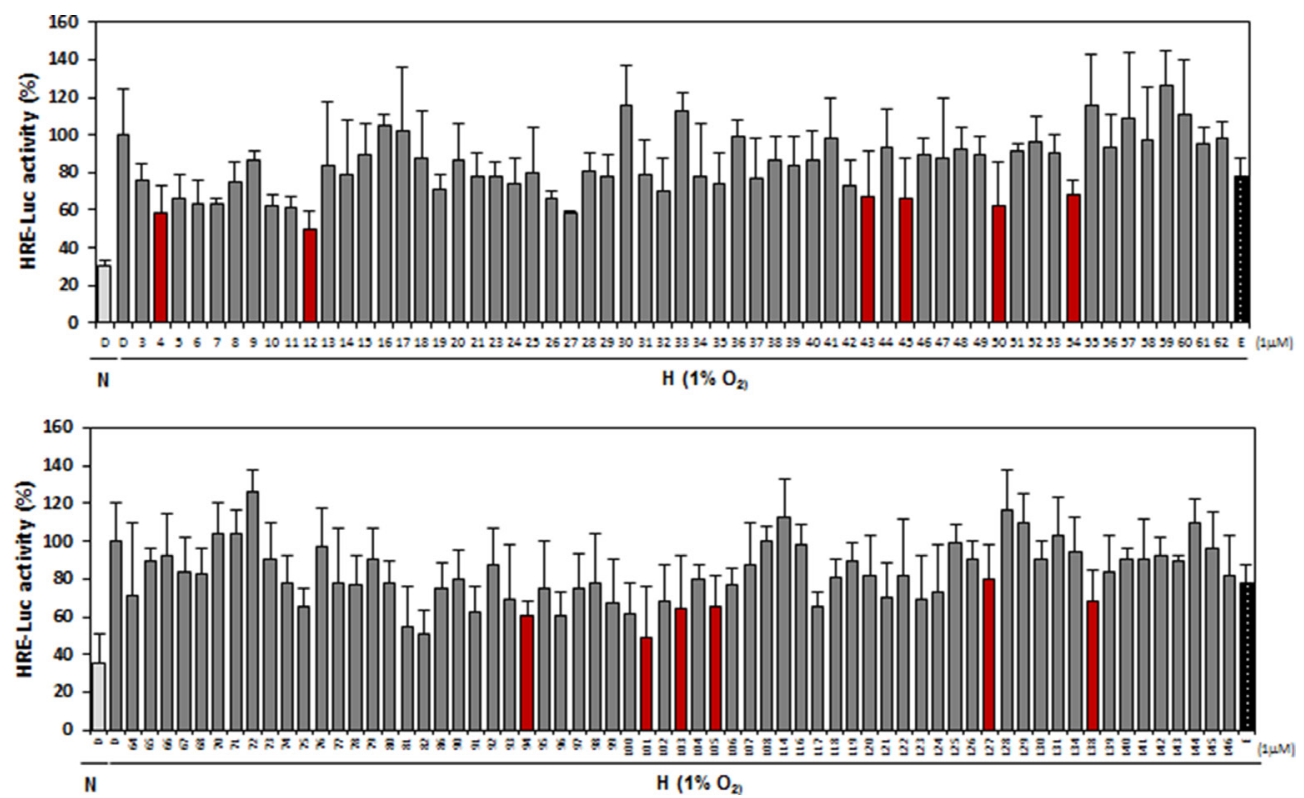

Figure 1: Screening of 144 compounds from an in-house chemical library for inhibition of HIF-1 activity. HEK-293 cells were co-transfected with luciferase reporter plasmids (pGL3-HRE-luciferase) and Renilla vector (pRL-SV40). Cells were exposed to hypoxic conditions in the presence or absence of chemicals for $24 \mathrm{~h}$, and were then lysed for assays of luciferase activity. Echinomycin (E), a known HIF-1 $\alpha$ inhibitor, was used as a positive control. N, normoxia, H, hypoxia. Three independent experiments were performed in triplicate.

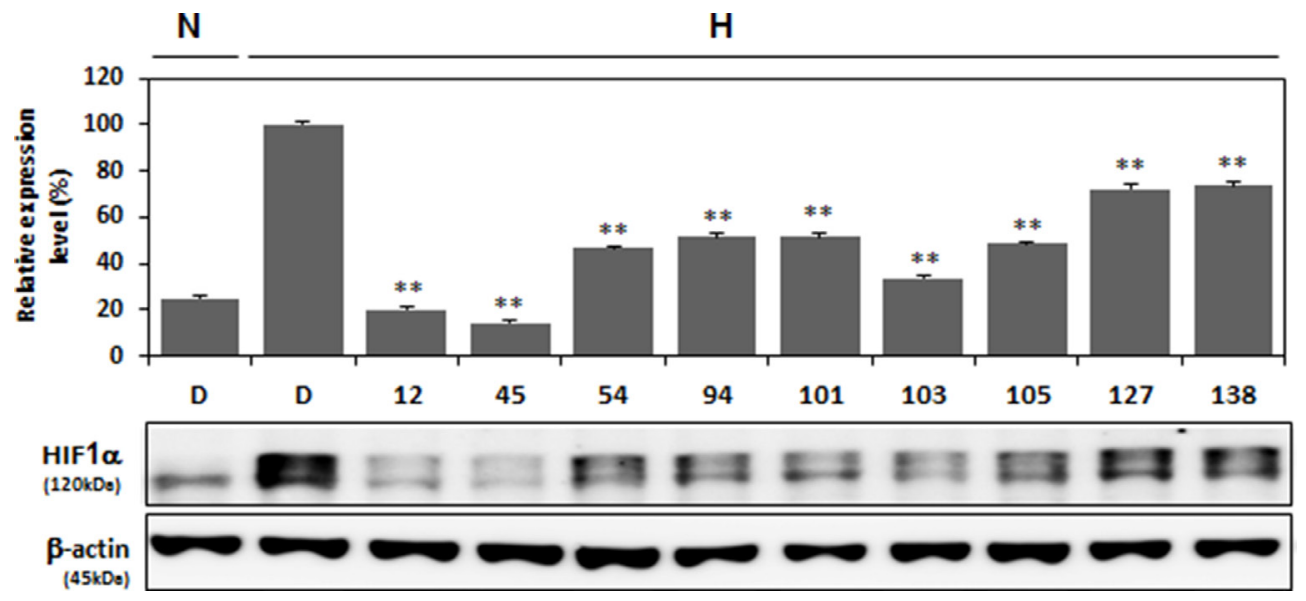

Figure 2: Decreased expression of HIF-1a protein under hypoxic conditions by nine selected compounds. A549 cells were treated with nine compounds (each at $1 \mu \mathrm{M}$ concentration) that had been effective in inhibiting HRE luciferase reporter activity (results shown in Figure 1) (red bar). Treatment was under hypoxic conditions for $16 \mathrm{~h}$. Cells were then lysed for western blot analysis, which was conduced with antibodies against HIF-1 $\alpha$ and $\beta$-actin. Expression levels were quantified by ImageJ (NIH, Bethesda, MO, USA) and graphed. $* * P<0.01$ versus $1 \% \mathrm{O}_{2}$ DMSO (D)-treated control group. 
HEK-293 cells, and by approx. 50\% in A549 cells (Figure 3B and 3C). GraphPad Prism software was used to calculate the values of half maximal effective concentrations $\left(\mathrm{EC}_{50}\right)$; we determined that the half maximal inhibitory concentrations $\left(\mathrm{IC}_{50}\right)$ of Compound 12 necessary for the inhibition of HIF$1 \alpha$ protein levels in HEK-293 cells and A549 cells were $23.96 \mathrm{nM}$ and $1.88 \mathrm{nM}$, respectively (Figure 3D and 3E). When compared to other HIF-1 $\alpha$ inhibitors, such as YC-1 $(2-50 \mu \mathrm{M})$ [21], LW6 (2.5-3 $\mu \mathrm{M})$ [22], echinomycin $(1.2 \mathrm{nM})$, bortezomib $(0.6-30 \mathrm{nM})$ [23], Apigenin $(10-90 \mu \mathrm{M})$ [24], and recently developed SYP-5 (10 $\mu \mathrm{M})$ [25]. Compound 12 has a significantly potent inhibitory effect on HIF-1 $\alpha$ protein levels.

\section{Compound 12 inhibits HIF-1a protein stability via increased ubiquitination}

To further confirm the effects of Compound 12 on the inhibition of HIF-1 $\alpha$ protein expression, we performed an immunofluorescent assay in A549 cells. Cells were treated with Compound 12 (1-100 nM) for $16 \mathrm{~h}$ under hypoxic conditions, and were then fixed with paraformaldehyde. Fixed cells were processed to allow immunostaining of HIF-1 $\alpha$ by a HIF-1 $\alpha$ antibody. Under hypoxic conditions, untreated cells showed
HIF-1 $\alpha$ accumulated in the nucleus; by contrast, under the same conditions, cells treated with Compound 12 showed that accumulation of nuclear HIF-1 $\alpha$ had been inhibited in dose-dependent manner. However, this did not affect the subcellular localization of HIF-1 $\alpha$ (Figure 4A). This suggests that Compound 12 does not induce cytosolic translocation of HIF- $1 \alpha$, but rather reduces the protein's stability.

We then determined the half-life of HIF-1 $\alpha$ in the presence or absence of Compound 12. A549 cells were treated with Compound 12 at $10 \mathrm{nM}$, under hypoxic conditions for $16 \mathrm{~h}$, and then were immediately treated with cycloheximide $(\mathrm{CHX}$, an inhibitor of protein synthesis). The half-life $\left(\mathrm{t}_{1 / 2}\right)$ of HIF-1 $\alpha$ protein was $12.4 \mathrm{~min}$ in control cells, but in the presence of Compound 12 , HIF-1 $\alpha$ was degraded two times faster than control cells; i.e., $\mathrm{t}_{1 / 2}$ of HIF-1 $\alpha$ was 6.1 min (Figure 4B), indicating that Compound 12 promotes HIF- $1 \alpha$ protein degradation.

Because in the $\mathrm{O}_{2}$-dependent degradation pathway PHDs hydroxylate the proline residues of HIF-1 $\alpha$ in its $\mathrm{O}_{2}$-dependent degradation (ODD) domain [26], expression of hydroxylated (OH)-HIF-1 $\alpha$ at proline 402 and 564, and PHD2 was investigated. Compound 12 increased hydroxylation of HIF-1 $\alpha$ in a dose-dependent manner, and PHD2 levels were increased even at the lowest dose $(1 \mathrm{nM})$ of Compound 12, suggesting that

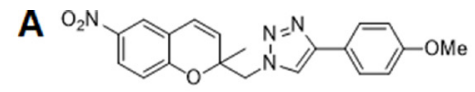

B

C
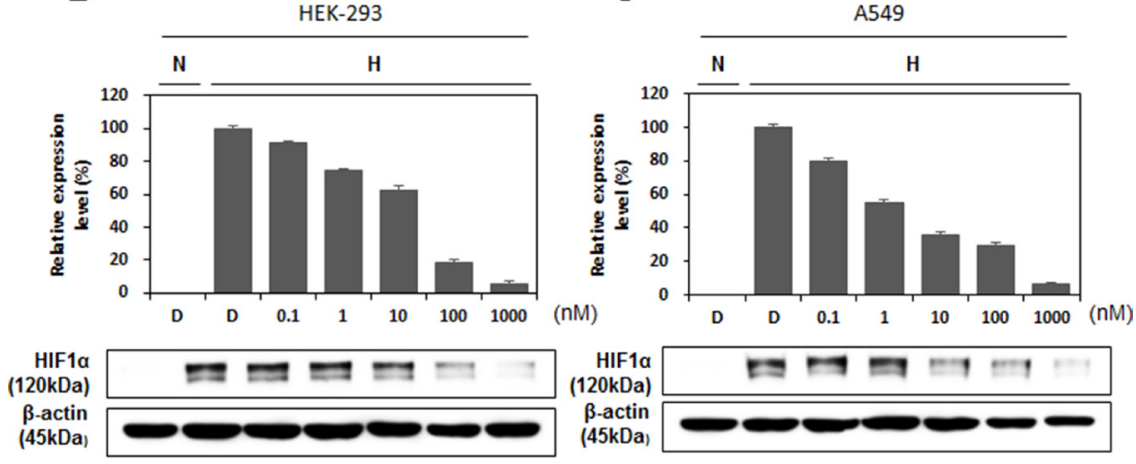

D

E
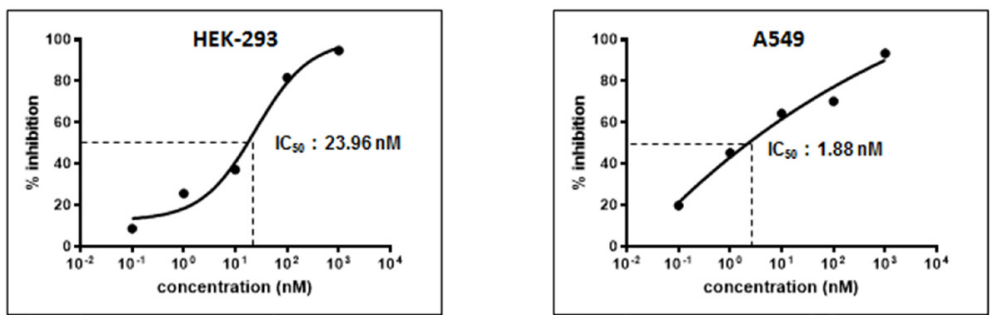

Figure 3: Chemical structure of Compound 12 and its dose-dependent inhibitory effects on HIF-1a expression. (A) Chemical structure of Compound 12: 4-(4-methoxyphenyl)-1-((2-methyl-6-nitro-2H-chromen-2-yl)methyl)-1H-1,2,3-triazole. (B, C) After HEK-293 cells (B) and A549 cells (C) were treated with Compound 12 (at concentrations of $0 \mathrm{nM}, 0.1 \mathrm{nM}, 1 \mathrm{nM}, 10 \mathrm{nM}$, $100 \mathrm{nM}$, and $1000 \mathrm{nM}$ ) under hypoxic conditions for $16 \mathrm{~h}$, expression of HIF-1 $\alpha$ was determined by western blot analysis and then graphed. $(\mathbf{D}, \mathbf{E})$ Half maximal inhibitory concentration $\left(\mathrm{IC}_{50}\right)$ values were calculated using GraphPad Prism software, using the quantified HIF-1 $\alpha$ levels determined in $\mathrm{B}$ and $\mathrm{C}$. 
Compound 12 regulates HIF-1 $\alpha$ degradation via increased hydroxylation of the HIF-1 $\alpha$ ODD domain (Figure 4C). We also determined that Compound 12 did not inhibit HIF-1 $\beta$ expression (Figure 4C). To further confirm the involvement of PHD2 in HIF-1 $\alpha$ degradation by Compound 12, two different small interfering (si) RNA of PHD2 were used. Decreased expression of HIF-1 $\alpha$ by Compound 12 under hypoxic conditions was recovered by knockdown of PHD2 (Figure 4D). Next, to check whether Compound 12 changes the ubiquitination status of HIF-1 $\alpha$, cells were treated with MG132 (a proteasome inhibitor) while under hypoxic conditions, and in the presence or absence of Compound 12. Cell lysates were immunoprecipitated (IP) with HIF-1 $\alpha$ antibody, and then were immunoblotted (IB) with anti-ubiquitin antibody. Compared to normoxic conditions, ubiquitination of HIF-1 $\alpha$ under hypoxic conditions (and in the absence of Compound 12) clearly decreased; however, in the presence of Compound 12, ubiquitination of HIF-1 $\alpha$ under hypoxic conditions significantly increased, compared to normoxic control cells (Figure 4E). These results suggest that Compound 12 inhibits HIF-1 $\alpha$ protein stability by promoting HIF-1 $\alpha$ protein degradation via increased proline hydroxylation and subsequent ubiquitination.

\section{Compound 12 suppresses HIF-1 $\alpha$ target gene expression and angiogenesis}

As HIF- $1 \alpha$ regulates transcription of its target genes, which are involved in angiogenesis, glucose metabolism, and metastasis in tumor progression [27, 28], we determined the effects of Compound 12 on HIF-1 target gene expression at the mRNA level by semiquantitative RT-PCR. As expected, Compound 12 suppressed the mRNA levels of VEGF, aldolase C (ALDOC), carbonic anhydrase 9 (CA9), glucose transporter 1 (GLUT1), and chemokine receptor type 4 (CXCR4), in a dose-dependent manner (Figure 5A). Among these, VEGF is a secreted protein and is one of the most potent contributors to tumor angiogenesis and metastasis. Thus, we checked secreted VEGF protein levels in culture media via ELISA. In cells under hypoxic conditions for $16 \mathrm{~h}$ (but in the absence of Compound 12), secreted VEGF levels were increased by 1.7-fold when compared to normoxic conditions; however, Compound 12 significantly suppressed hypoxia-induced VEGF secretion, in a dose-dependent manner (Figure 5B).

The inhibitory effects of Compound 12 on VEGF secretion motivated us to investigate whether it also suppressed VEGF-induced angiogenesis. During the process of angiogenesis, vascular endothelial cells proliferate, migrate into avascular regions, and mature into the vessel structure [29]. To check this process, we cultured HUVECs and determined cell proliferation using the BrdU uptake assay. Serum-starved HUVECs were treated with Compound 12 in the presence or absence of $20 \mathrm{ng} / \mathrm{mL}$ VEGF for $16 \mathrm{~h}$. VEGF increased endothelial cell proliferation by 1.8 -fold, but Compound 12 significantly inhibited VEGF-induced proliferation, in did so in a dosedependent manner (Figure 5C). Endothelial migration and tube formation abilities induced by VEGF were also significantly inhibited by treatment with Compound 12 (Figure 5D and 5E). To confirm these in vitro results in vivo, we performed a chick CAM assay. Similar to retinoic acid (RA, the positive control), Compound 12 significantly suppressed CAM angiogenesis, in a dosedependent manner (Figure 5F).

\section{Cotreatment of Compound 12 with a chemotherapeutic agent suppresses allogaft tumor growth and angiogenesis}

HIF-1 $\alpha$ is synthesized by growth factor signaling pathways, such as those of EGFR [30] [31]. Inhibition of HIF-1 $\alpha$ in its pathways of synthesis, as well as in its pathway of degradation, would seem to make for a more efficient anti-cancer/anti-angiogenesis treatment. To confirm this, we performed a tumor allogaft experiment using Lewis lung carcinoma (LLC) cells. $1 \times 10^{6}$ LLC cells were inoculated into the mouse flank subcutaneously (s.c.), and treatment with Compound $12(5 \mathrm{mg} / \mathrm{kg})$ and $/$ or gefitinib (an EGFR inhibitor, $50 \mathrm{mg} / \mathrm{kg}$ ), via intraperitoneal (i.p.) administration, was performed every other day for 20 days. At Day 20, mice were sacrificed and tumor tissue was fixed in formaldehyde for $1 \mathrm{~h}$ for further histological examination. Individually, gefitinib alone and Compound 12 alone both inhibited tumor growth significantly; administered as a combination, however, they suppressed tumor growth more effectively than did either drug alone (Figure 6A). During the entire treatment period, no noticeable alteration of mice body weight was observed in all groups (Supplementary Figure S3). As shown in Figure 6B, tumor weight was significantly decreased in the Compound 12-treated group, and to an extent, similar or identical to the gefitinib-treated group. To confirm the effect of Compound 12 on angiogenesis, we analyzed angiogenesis using the Matrigel plug assay. As expected, anti-angiogenic activity was increased in tumors treated either with Compound 12 or with gefitinib (Figure 6C). To confirm the effects of Compound 12 on anti-angiogenesis, we sectioned the tumor tissues to determine microvessel density (MSD) via immunohistochemistry (using CD31 antibody). MSD in the vehicle-treated control tumor mass was very high, but treatment with Compound 12 or gefitinib significantly decreased MSD. Cotreatment with Compound 12 and gefitinib synergistically decreased MSD (Figure 6D).

We determined levels of hypoxia in tissues via: 1) antibodies against the hypoxic cell marker pimonidazole (PIMO), and 2) checking expression levels of carbonic anhydrase (CA9), a downstream target of HIF-1. We found that levels of both PIMO and CA9 were significantly diminished in tumors treated with either Compound 12 
alone or gefitinib alone, and that PIMO/CA9 levels had decreased synergistically in the group treated with the combination of Compound 12 plus gefitinib (Figure 6E). It is likely that cells expressing the Ki-67 protein (a marker for cellular proliferation) were also significantly decreased in tumors treated either with Compound 12 or with gefitinib (Figure 6F). Taken together, these results suggest that Compound 12, a benzopyranyl 1,2,3-triazole compound, is a novel HIF-1 $\alpha$ inhibitor. It seems to have suppressed HIF-1 $\alpha$ stability and activity in cancer cells, and to have synergistically inhibited tumor growth when combined with other chemotherapeutic agents. These results suggest that this benzopyranyl 1,2,3-triazole compound can be used in combination therapies, with other targeted chemotherapeutic agents, to inhibit tumor growth and intratumoral angiogenesis.
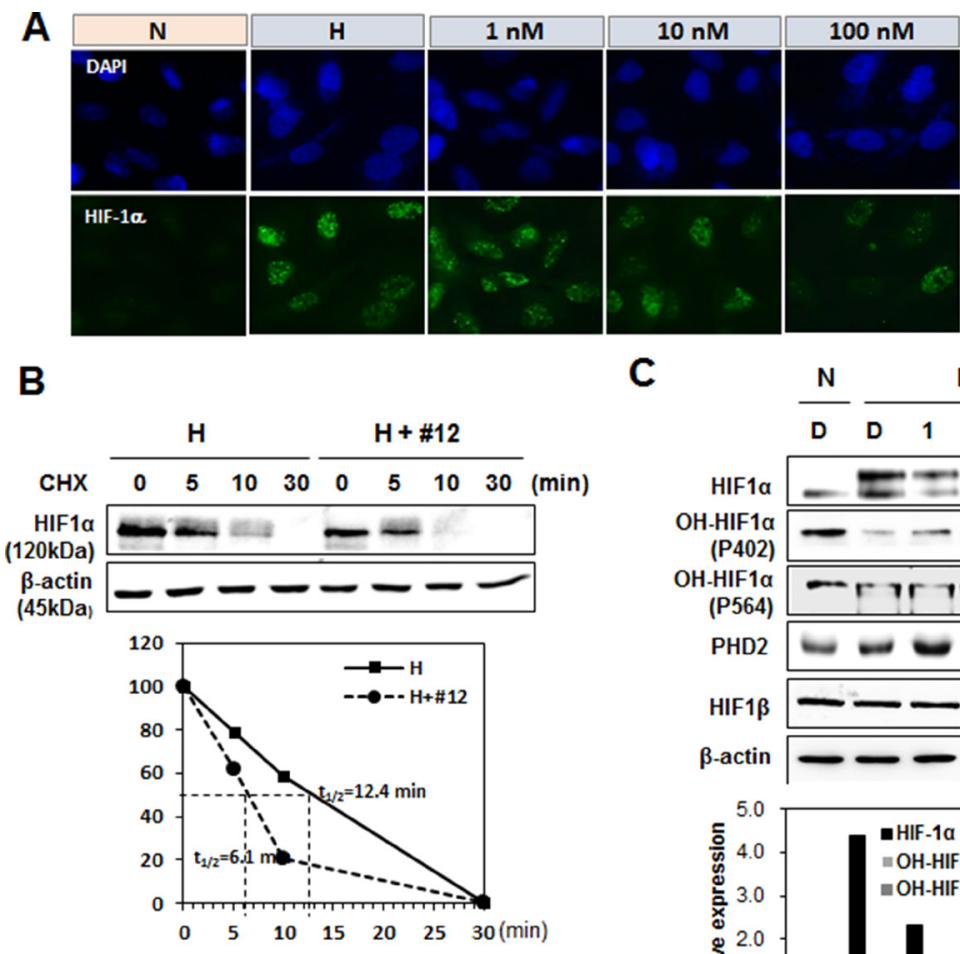

D

C
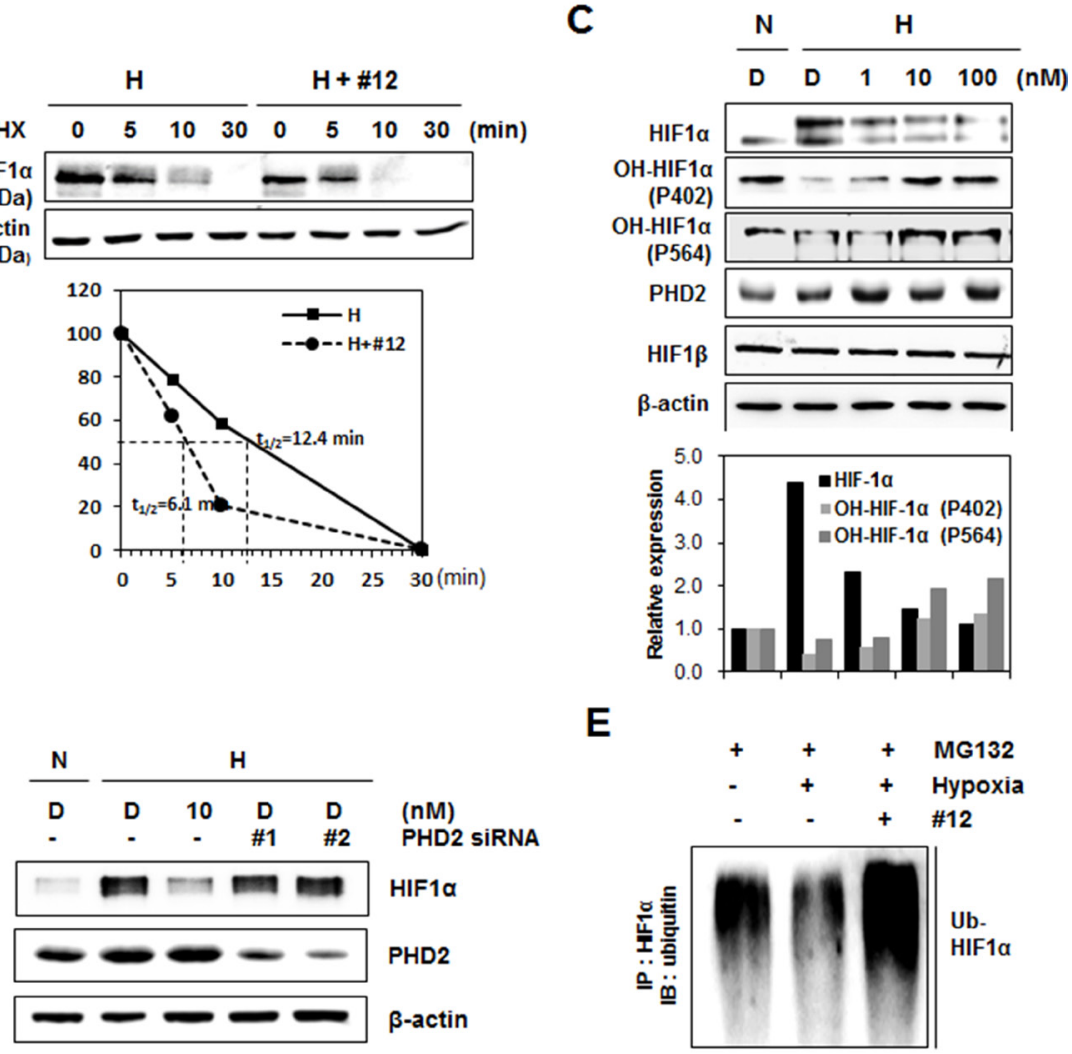

$\mathbf{E}$

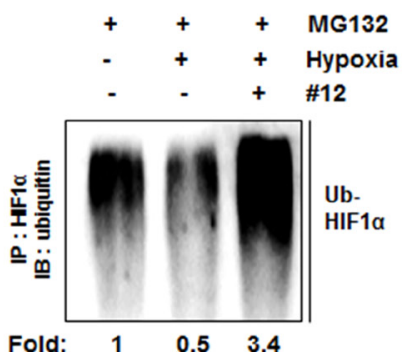

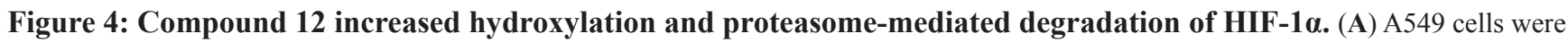
treated with Compound 12 (at concentrations of $0 \mathrm{nM}, 1 \mathrm{nM}, 10 \mathrm{nM}$, and $100 \mathrm{nM}$ ) for $16 \mathrm{~h}$. Cells were fixed with paraformaldehyde; an immunofluorescence assay was then performed using anti-HIF-1 $\alpha$ antibodies and Alexa Fluor 488-labeled secondary antibodies (green). Nuclei were stained with DAPI. N, normoxia; H, hypoxia. (B) A549 cells were treated with Compound 12 (10 nM concentration) and exposed to hypoxic conditions for $16 \mathrm{~h}$. Cells were immediately treated with cycloheximide $(\mathrm{CHX}, 100 \mu \mathrm{g} / \mathrm{mL})$ for the time indicated, and HIF-1 $\alpha$ protein levels were determined by western blotting. $\beta$-actin was used as an internal control. Half-life $\left(\mathrm{t}_{1 / 2}\right)$ of HIF-1 $\alpha$ protein was determined using relative expression levels of HIF-1 $\alpha$. (C) A549 cells were treated with Compound 12 (at concentrations of $0 \mathrm{nM}, 1 \mathrm{nM}$, $10 \mathrm{nM}$, and $100 \mathrm{nM}$ ) for $16 \mathrm{~h}$. The expression levels of HIF-1 $\alpha$, hydroxylated (OH)-HIF-1 $\alpha$ at P402 or P564, and PHD2 were determined via western blotting using specific antibodies. N, normoxia; H, hypoxia. (D) A549 cells were transfected with two kinds of small interfering RNAs targeting PHD2 and then treated with Compound 12 under hypoxic exposure for $16 \mathrm{~h}$. Cell lysates were immunoblotted with an anti-HIF-1 $\alpha$ and PHD2 antibody. (E) After A549 cells were treated with Compound 12 for 16 h, cells were treated with MG132 (20 $\mu$ M) for $4 \mathrm{~h}$. Cell lysates were immunoprecipitated (IP) with anti-HIF-1 $\alpha$ antibody, and were then immunoblotted (IB) with anti-ubiquitin antibody. Relative levels of ubiquitinated HIF-1 $\alpha$ were quantified and graphed. 


\section{DISCUSSION}

To improve cancer therapy, manipulation of the tumor microenvironment has been continuously investigated. The responses of tumors to radiation and chemotherapeutic agents depend on factors in the tumor microenvironment, including tumor cell-extracellular matrix interaction [32], tumor-immune cell interaction $[33,34]$, and tumor oxygenation [34]. In the 1970's, Folkman proposed the concept of targeting the blood
A

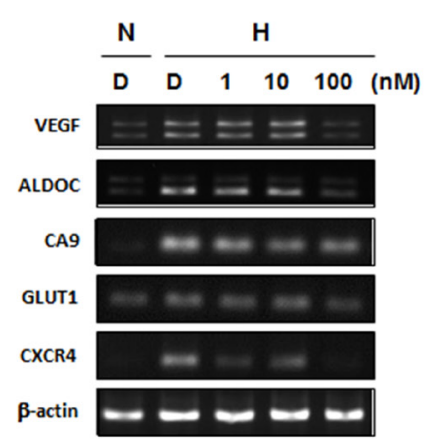

C

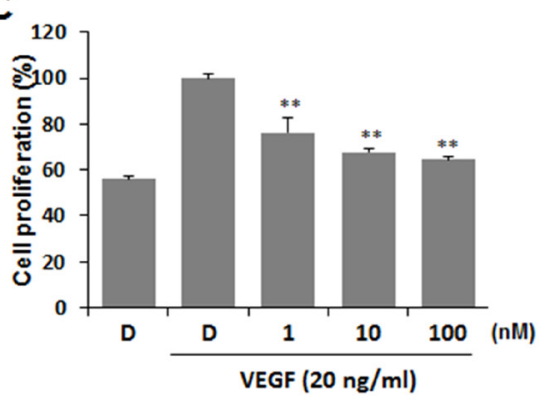

E
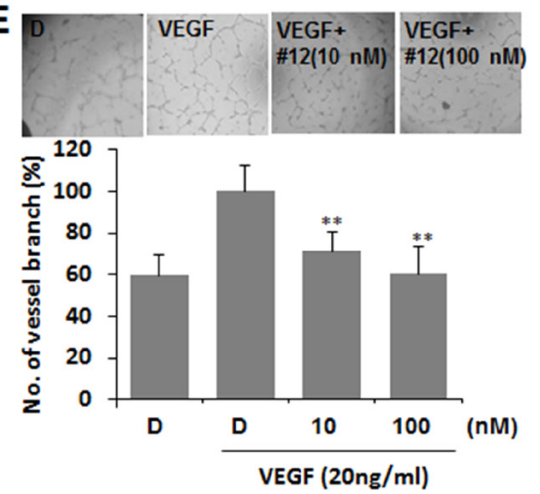

B

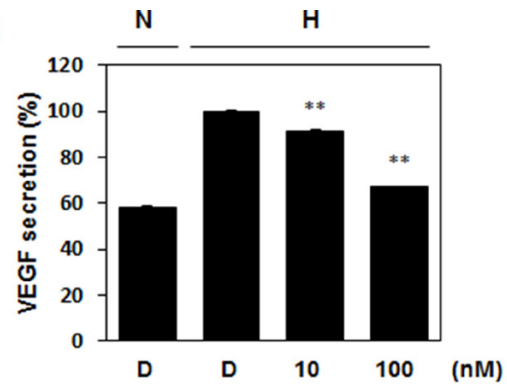

D

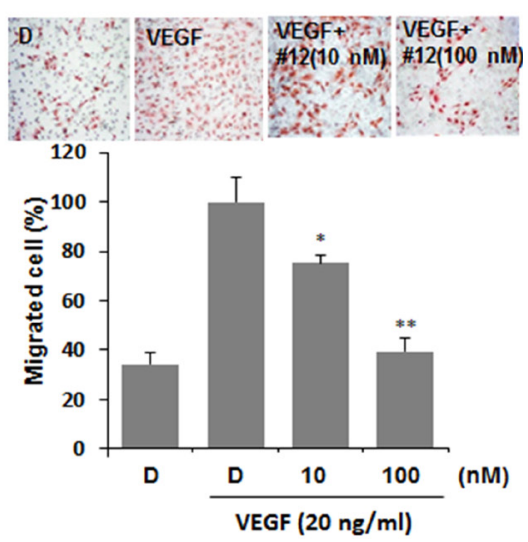

$F$

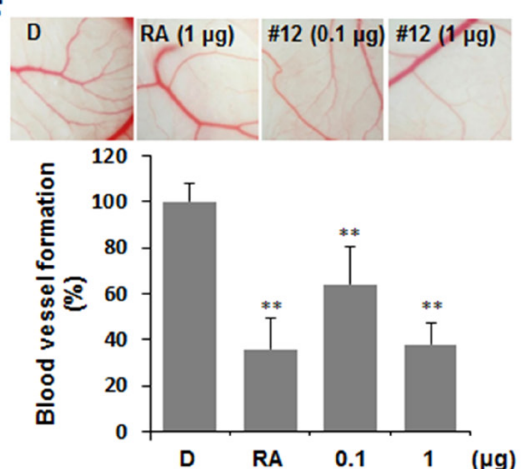

Figure 5: Compound 12 suppressed HIF-1 $\alpha$ target gene expression, and confirmation of in vitro results via determination of effects on angiogenesis in vivo. (A) A549 cells were treated with Compound 12 (at concentrations of $0 \mathrm{nM}, 1 \mathrm{nM}, 10 \mathrm{nM}$, and $100 \mathrm{nM}$ ) for $16 \mathrm{~h}$. The mRNA levels of HIF-1 $\alpha$ target genes were determined by semiquantitative RT-PCR. $\beta$-actin was used as an internal control. D. DMSO vehicle control. N, normoxia; H, hypoxia. (B) A549 cells were treated with serum-reduced culture media containing Compound 12 (at concentrations of $0 \mathrm{nM}, 10 \mathrm{nM}$, and $100 \mathrm{nM}$ ) for $16 \mathrm{~h}$. Media supernatant was collected, and secreted VEGF was determined by ELISA after removal of cellular debris. N, normoxia; H, hypoxia. $* * P<0.01$ versus hypoxia (H) DMSO (D)-treated control. (C) HUVECs were treated with Compound 12, at the indicated concentrations, in the presence of VEGF (20 ng/mL) for $24 \mathrm{~h}$ in $1 \%$ serumcontaining media. BrdU proliferation assays were then performed. $* * P<0.01$ versus VEGF-treated DMSO (D) group. (D). HUVECs were seeded into the upper chamber of the transwell; VEGF $(20 \mathrm{ng} / \mathrm{mL})$ and Compound 12, at the indicated concentrations, were then added to the lower chamber, and the transwell was incubated at $37^{\circ} \mathrm{C}$ for $24 \mathrm{~h}$. Cells that migrated through the membrane $(8 \mu \mathrm{m}$ pore size $)$ were stained with hematoxylin and eosin, pictured as shown in upper panel, and counted (graph). ${ }^{*} P<0.05,{ }^{* *} P<0.01$ versus VEGF-treated control. (E) HUVECs were seeded on Matrigel-coated 96 well plates and treated with Compound 12, at the indicated concentrations, in the presence of VEGF $(20 \mathrm{ng} / \mathrm{mL})$ for $24 \mathrm{~h}$. Changes in cellular morphology were observed under a microscope and photographed at $100 \times$ magnification. Statistical significance: $* P<0.05, * * P<0.01$ versus VEGF treated control. (F) Compound $12(0.1 \mu \mathrm{g}$ and $1 \mu \mathrm{g}$ dosages $)$ and retinoic acid (RA, positive control) were applied to the ED 4.5 CAM for two days, neovessel formation from the large vessels was observed, and percentages of positive angiogenic eggs (from total eggs tested) were calculated. 
vessels in tumors, to starve the tumor of oxygen and nutrients [35]; however, hypoxia increases HIF-1 $\alpha$ and its target, VEGF, resulting in increased blood vessels in the tumor [36]. However, as tumor vasculatures have leaky and chaotic structures, hypoxic regions are generated again as tumors grow [37]. In turn, HIF- $1 \alpha$ is overexpressed by recurrent hypoxia, causing increased activity of HIF target genes involved in angiogenesis, metabolism, metastasis, and radioresistance, and chemoresistance $[34,38]$. In addition, targeting angiogenesis via treatment with VEGF monoclonal antibodies increases the hypoxic region, again resulting in HIF- $1 \alpha$ accumulation and consequential increases in the expression of HIF target genes such as VEGF [39, 40]. Therefore, the collective effects of targeting HIF-1 $\alpha$ have more potential for inhibiting tumor growth than does targeting angiogenesis alone. Here we suggest that $5 \mathrm{mg} / \mathrm{kg}$ body weight dose of HIF-1 $\alpha$ inhibitor, Compound 12 in combination therapy, $1 / 10$ of gefitinib, because of possible toxicity but it was sufficient to be effective (Figure 6). However, owing to
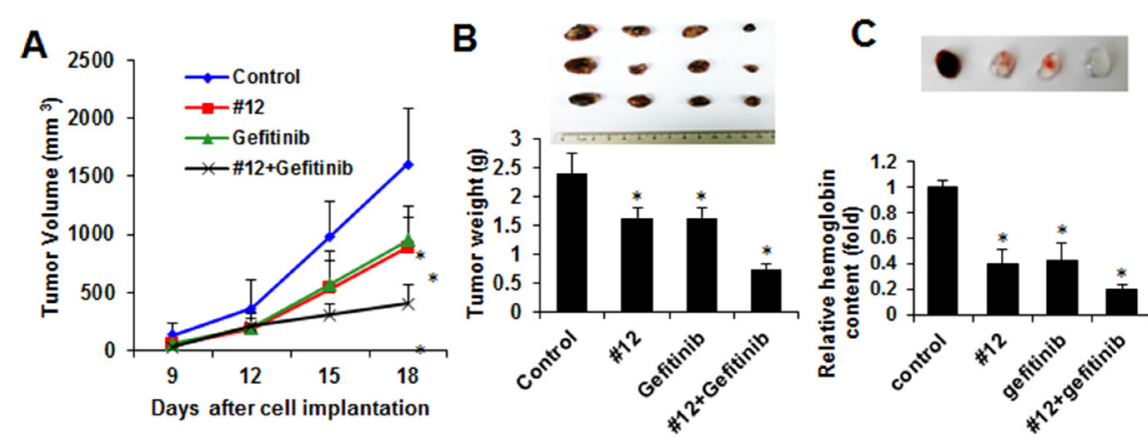

D
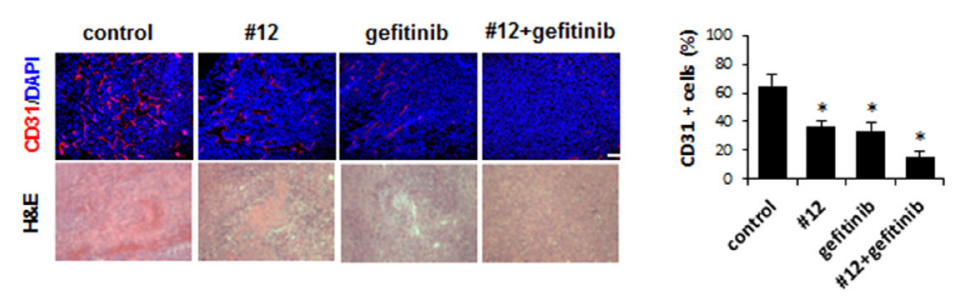

$\mathbf{E}$
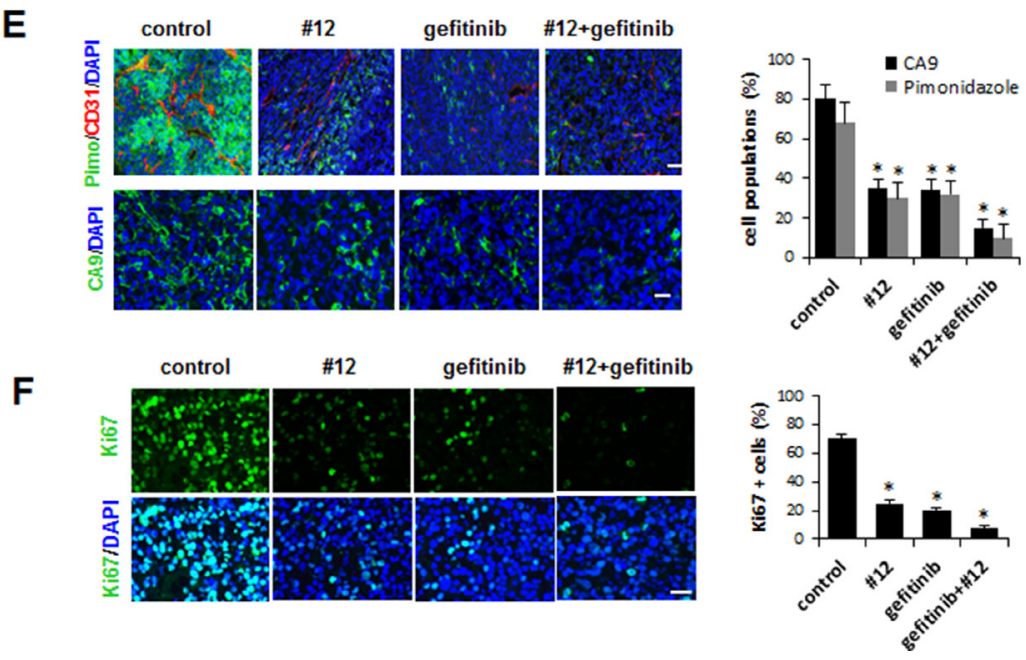

Figure 6: Compound 12 suppressed allogaft tumor growth and enhanced the effects of a chemotherapeutic agent. (A, B) Lewis lung carcinoma cells were inoculated into flanks of C57BL/6J mice (Day 0). From two days after inoculation, mice were treated intraperitoneally with Compound $12(5 \mathrm{mg} / \mathrm{kg}$ body weight) and gefitinib ( $50 \mathrm{mg} / \mathrm{kg}$ body weight), three times a week, for 18 days and then sacrificed. Tumor size (A) and tumor weight (B) were measured three times a week and on the final day, respectively. Tumor masses were photographed and shown in box below the graph. ${ }^{*} P<0.05$ versus control group. (C) Matrigel was treated with DMSO, Compound $12(100 \mathrm{nM})$, and gefitinib $(5 \mu \mathrm{M})$ and inoculated in the flank of C57BL/6J mice. After 10 days matrigel plug was removed and photographed. The content of hemoglobin was quantified and graphed. (D) Tumor tissue sections (10 $\mu \mathrm{m})$ indicated were stained with H\&E and immunostained with anti-CD31 antibody to detect microvessel density; CD31+ cell percentages were then calculated and graphed. Scale bar, $100 \mu \mathrm{m} . * * P<0.05$ versus control group. (E) Images and quantitative comparisons (graph) for hypoxic regions, immunostained CA9 protein, and microvessels (CD31+ cells) in tumor center regions are shown. Scale bar, $100 \mu \mathrm{m}$. ** $P<0.05$ versus control group. (F) Images and quantitative comparisons (graph) for Ki67+ proliferating cells in tumor center regions are shown. Scale bar, $100 \mu \mathrm{m}$. $* * P<0.05$ versus control group. 
the complexity of the HIF-1 transcriptome, inhibition of HIF-1 $\alpha$ may also result in unpredictable outcomes in human patients [41]. Among known HIF-1 $\alpha$ inhibitors, Campothecin has topoisomerase I inhibitory activity [42] and PX-12 (1-methylpropyl 2-imidazolyl disulfide) inhibits thioredoxin-1 (Trx-1) activity [43], suggesting the probability of Compound 12 having other unspecific effect besides HIF-1 $\alpha$ inhibitory activity. Furthermore, the powerful selection occurring in cancer cells exposed to several independent, targeted therapies suggests that administration of multiple agents simultaneously is essential for the successful treatment of human cancer [44-46]. Therefore, the use of HIF-1 $\alpha$ inhibitors as anticancer agents must be adopted within the overall strategy of combination therapy [41]. We used gefitinib to inhibit EGFR, and Compound 12 to inhibit HIF-1 $\alpha$. We determined that inhibition of EGFR functions to decrease both HIF-1 $\alpha$ synthesis and VEGF expression. Surprisingly, erlotinib-another EGFR inhibitordecreases hypoxic regions in tumor tissues and induces vascular normalization in tumors, which, in turn, improves the efficacies of chemotherapy and radiotherapy [47]. The results of our allogaft experiments showed that the combination of Compound 12 and gefitinib decreased the size of the hypoxic region and of the tumor itself through increased apoptosis and decreased angiogenesis. From the erlotinib study [47], we can speculate that Compound 12 might enhance the effects of gefitinib not only by inhibiting HIF-1 $\alpha$ synthesis, but also by inducing vascular normalization, resulting in improved vascular delivery of gefitinib to the tumor tissues. The effects of Compound 12 on tumor vascular normalization in spontaneous or allogaft tumors and the mechanisms by which these effects are achieved should be further investigated.

The $\mathrm{IC}_{50}$ of Compound 12 for the inhibition of HIF-1 $\alpha$ protein levels in the hypoxic cells we used was around 2-24 $\mathrm{nM}$. As the $\mathrm{IC}_{50}$ values of other HIF-1 $\alpha$ inhibitors are 2-50 $\mu \mathrm{M}$ for $\mathrm{YC}-1$ [21], 2.5-3 $\mu \mathrm{M}$ for LW6 [22], 10-90 $\mu \mathrm{M}$ for Apigenin [24], and $10 \mu \mathrm{M}$ for SYP-5 [25], it is clear that Compound 12 is a far more potent inhibitor of HIF-1 $\alpha$ activity. Another HIF-1 $\alpha$ inhibitor, Bortezomib inhibits p300-HIF-1 $\alpha$ binding at nanomolar concentrations $(0.6-30 \mathrm{nM})$, almost equivalent to Compound 12 to repress HIF- $1 \alpha$ protein expression and nuclear accumulation by inhibiting both PI3K/Akt/ mTOR and MAPK pathways in prostate cancer cells [23]. Treatments using Compound 12 at nanomolar concentrations could easily be combined with other targeted therapies such as treatment with gefitinib, Herceptin (trastuzumab), and other medicines. In conclusion, Compound 12, a benzopyranyl 1,2,3-triazole, demonstrates strong inhibitory activity against HIF-1 $\alpha$ stability and transactivation, thereby showing both anti-angiogenic and anti-tumor activity. Furthermore, the addition of gefitinib enhanced the effects of Compound 12 on anti-tumor activity by decreasing hypoxia-mediated tumor growth.
Investigations to confirm the direct target(s) of Compound 12 , and to develop simpler and more potent benzopyranyl 1,2,3-triazole analogues, should be undertaken.

\section{MATERIALS AND METHODS}

\section{Materials}

One hundred forty-four small molecules not previously evaluated for their pharmacological effects were obtained from our in-house chemical library [15, 16, 48, 49] (Kyungpook National University, College of Pharmacy, Laboratory of Combinatorial and Medicinal Chemistry) and screened for HIF-1 $\alpha$ inhibition. Chemical compounds were dissolved in dimethyl sulfoxide (DMSO) at a stock concentration of $5 \mathrm{mM}$.

\section{Mice}

Animal experiments were performed using C57BL/6J mice (SLC, Japan), which were handled in strict compliance with the guidelines for care and use of laboratory animals issued by the institutional ethical animal care committee of Kyungpook National University (Daegu, Korea). Mice were maintained under specific pathogen-free conditions.

\section{Cell culture and hypoxic conditions}

HEK-293 human embryonic kidney epithelial cells (American Type Culture Collection, Manassas, VA, USA) were maintained in Dulbecco's modified Eagle's medium (DMEM, Hyclon, Logan, UT, USA) with 10\% fetal bovine serum (FBS, Hyclon, Logan, UT, USA) and $1 \%$ antibiotics (100 units/mL penicillin, $100 \mathrm{mg} / \mathrm{mL}$ streptomycin, Invitrogen, Carlsbad, CA, USA). A549 adenocarcinomic human alveolar basal epithelial cells were maintained in Roswell Park Memorial Institute medium (RPMI) 1640 (Hyclon, Logan, UT, USA) containing $10 \%$ FBS and $1 \%$ antibiotics. Human umbilical vein endothelial cells (HUVECs, 4-10 passages) were grown on $1 \%$ gelatin-coated culture plates in Medium 199 (M199, Hyclon, Logan, UT, USA) supplemented with $20 \% \mathrm{FBS}, 1 \%$ antibiotics, basic fibroblast growth factor (bFGF, $2 \mathrm{ng} / \mathrm{mL}$ ), and heparin ( 5 unit/mL, Sigma, St Louis, MO). All cells were maintained at $37^{\circ} \mathrm{C}$ in an incubator with a humidified atmosphere of $5 \% \mathrm{CO}_{2}$ and 95\% air. For hypoxic condition, cells were cultured in hypoxic chambers (Thermo Scientific, Waltham, MA, USA and Astec, Fukuoka, Japan) at 5\% $\mathrm{CO}_{2}$, with $1 \% \mathrm{O}_{2}$ balanced with $\mathrm{N}_{2}$.

\section{MTT assay}

Cells were seeded onto 96-well plates at a density of $5-10 \times 10^{3}$ cells/well, and then incubated for $24 \mathrm{~h}$. 
The media was removed, and the cells were treated with various concentrations of chemicals. After the cells were incubated for $24 \mathrm{~h}, 3-(4,5$-dimethylthiazol-2-yl)2,5-diphenyltetrazolium bromide (MTT, AMRESCO, Solon, OH, USA) solution was added to each well and incubated for another $4 \mathrm{~h}$ at $37^{\circ} \mathrm{C}$. The resulting formazan crystals were dissolved in DMSO (100 $\mu \mathrm{L} /$ well), and the absorbance of the plate was read with a microplate reader (Infinite M200 Pro, TECAN, Männedorf, Switzerland) at $540 \mathrm{~nm}$. Three replicate wells were used for each analysis.

\section{Dual luciferase assay}

HEK-293 cells were seeded onto 96-well plates at a density of $5 \times 10^{3}$ cells/well, and allowed to attach for $24 \mathrm{~h}$. Next, cells were co-transfected with pGL3-HREluciferase plasmid containing five copies of HREs from human vascular endothelial growth factor (VEGF) genes, and pRL-SV40 plasmid encoding Renilla luciferase, using Vivamagic Transfection Reagent (Vivagene, Seongnam, Korea), according to the manufacturer's instructions. After transfection, cells were treated with each chemical compound for $24 \mathrm{~h}$ before reporter assay. Luciferase assays were performed using the Dual-Glo Luciferase Assay System (Promega, Madison, WI, USA), according to the manufacturer's instructions. Briefly, Dual-Glo Reagent was added with an equivalent volume of culture medium to each well, and the wells were incubated for $10 \mathrm{~min}$. Firefly luminescence was measured using a microplate reader (Infinite M200 Pro, TECAN, Männedorf, Switzerland). Next, Dual-Glo Stop \& Glo Reagent was added with an equivalent volume of culture mediumto each well, and the wells were incubated for $10 \mathrm{~min}$. Renilla luminescence was measured using a microplate reader. Three replicate wells were used for each analysis, and the results were normalized to the activity of Renilla luciferase.

\section{Western blot analysis}

Proteins extracted from cells using PRO-PREP (iNtRon Biotech, South Korea) were separated by SDSPAGE and transferred to a nitrocellulose membrane (Whatman, Maidstone, UK). Membranes were blocked with 5\% skim milk in Tris-buffered saline (TBS) containing $0.1 \%$ Tween-20 for $30 \mathrm{~min}$ at room temperature (RT). After blocking, membranes were incubated with specific primary antibodies overnight at $4^{\circ} \mathrm{C}$, followed by incubation with horseradish peroxidase-conjugated mouse- or rabbit-IgG for $1 \mathrm{~h}$ at RT. Antibody binding was detected using an enhanced chemiluminescence (ECL) kit (BioRad, Hercules, CA) according to the manufacturer's instructions. Primary antibodies against the following factors were used: HIF-1 $\alpha$ (BD Biosciences, San Diego, CA, USA), HIF-1 $\beta$ (Cell Signaling Technology, Danvers, MA, USA), $\beta$-actin (Santa Cruz Biotechnology, Santa
Cruz, CA, USA), hydroxylated-HIF-1 $\alpha$ (P564) (Cell Signaling Technology, Danvers, MA, USA), and PHD2 (Abcam, Cambridge, UK).

\section{Immunofluorescence assay}

Cells were cultured on coverslips in four-well plates at a density of $1 \times 10^{5}$ cells/well, and allowed to attach for $24 \mathrm{~h}$. The media was removed; the cells were treated with various concentrations of chemicals, and the cells were incubated for $24 \mathrm{~h}$. Cells were then fixed with $4 \%$ paraformaldehyde (PFA) solution and permeabilized with $1 \%$ Triton X-100. Fixed cells were blocked with $0.5 \%$ bovine serum albumin (BSA)/phosphate-buffered saline (PBS) and incubated with HIF-1 $\alpha$ antibody (Santa Cruz Biotechnology, Santa Cruz, CA) overnight at $4^{\circ} \mathrm{C}$. Alexa Fluor 488-conjugated anti-mouse $\mathrm{IgG}$ was used as the secondary antibody, and 4',6-diamidino-2-phenylindole (DAPI) was used to label nuclei. Coverslips were mounted on slides, and cells were observed using fluorescence microscopy at 400X magnification (Carl Zeiss, AG, Germany).

\section{RNA isolation, reverse transcription-polymerase chain reaction (RT-PCR)}

Total RNA was extracted from cultured cells using TRIzol Reagent (Invitrogen, Carlsbad, CA, USA), and cDNA was synthesized from total RNA using Moloney murine leukemia virus (MMLV) reverse transcriptase (Bioneer, Daejeon, Korea). The conditions for semiquantitative PCR were 30 cycles of: denaturation $\left(94^{\circ} \mathrm{C} / 30 \mathrm{~s}\right)$, annealing $\left(50^{\circ} \mathrm{C} / 40 \mathrm{~s}\right)$, extension $\left(72^{\circ} \mathrm{C} / 40 \mathrm{~s}\right)$, and final extension $\left(72^{\circ} \mathrm{C} / 10 \mathrm{~min}\right)$. Table 1 summarizes the sequences of the primers used in this study. Amplification real-time PCR was performed using a SYBR Green PCR Master Mix (Applied Biosystems, CA, USA). Each PCR reaction contained cDNA with ten-fold dilution and gene-specific primers. The thermal cycle used was $2 \mathrm{~min}$ at $50^{\circ} \mathrm{C}, 10 \mathrm{~min}$ at $95^{\circ} \mathrm{C}$, and 40 cycles of $15 \mathrm{~s}$ denaturation at $95^{\circ} \mathrm{C}$ with $1 \mathrm{~min}$ annealing at $60^{\circ} \mathrm{C}$. Mean cycle threshold (CT) values were calculated for gene expression, with normalization to $\beta$-actin or glyceraldehyde 3-phosphate dehydrogenase (GAPDH) as an internal control. Each experiment was performed in triplicate, and means were calculated.

\section{Enzyme-linked immunosorbent assay (ELISA)}

The amounts of VEGF protein secreted by the cells into the medium was determined with a VEGF ELISA kit, according to the manufacturer's instructions (\#KHG0111, Invitrogen, Carlsbad, CA, USA). 
Table 1: Primer sequences for PCR

\begin{tabular}{|c|c|c|}
\hline nam & & Primer sequence \\
\hline \multirow{2}{*}{ VEGF } & Forward & 5'-ACCATGAACTTTCTGCTC-3' \\
\hline & Reverse & 5'-GGACGGCTTGAAGATATA-3' \\
\hline \multirow{2}{*}{ ALDOC } & Forward & 5'-TGAGCAGAAGAAGGAGTTGT-3' \\
\hline & Reverse & 5'-GGTCTCATGGAAGAAAATGA-3' \\
\hline \multirow{2}{*}{ CA9 } & Forward & 5'-GGAAGAAAACAGTGCCTATG-3' \\
\hline & Reverse & 5'-AGACCCCTCATATTGGAAGT-3' \\
\hline \multirow{2}{*}{ GLUT1 } & Forward & 5'-TACCCTGGATGTCCTATCTG-3' \\
\hline & Reverse & 5'-CACACAGTTGCTCCACATAC-3' \\
\hline \multirow{2}{*}{ CXCR4 } & Forward & 5'-GGCAGCAGGTAGCAAAGTGA-3' \\
\hline & Reverse & 5'-TGATGACAAAGAGGAGGTCG-3' \\
\hline \multirow{2}{*}{$\beta$-actin } & Forward & 5'-GACTACCTCATGAAGATC-3' \\
\hline & Reverse & 5'-GATCCACATCTGCTGGAA-3' \\
\hline
\end{tabular}

\section{Bromodeoxyuridine (BrdU) cell proliferation assay}

Human umbilical vein endothelial cells (HUVECs) were seeded onto 96 -well plates at a density of $5 \times 10^{3}$ cells/well, and allowed to attach for $24 \mathrm{~h}$. The media was replaced with low serum medium (1\% FBS in M199) for $16 \mathrm{~h}$, and the cells were treated with various concentrations of chemicals for $24 \mathrm{~h}$. Following incubation, cell proliferation was measured with a Cell Proliferation ELISA, BrdU kit (Roche, Mannheim, Germany), according to the manufacturer's instructions.

\section{In vitro cell migration assay}

Migration of endothelial cells was tested using the Transwell system ( $8 \mu \mathrm{m}$ pore size and $6.5 \mathrm{~mm}$ diameter) in 24-well plates (Corning Costar, Lowell, MA, USA). The lower sides of the filters were coated with $10 \mu \mathrm{L}$ of type I collagen $(0.5 \mathrm{mg} / \mathrm{mL})$. Chemicals were added to the lower chamber in the presence of VEGF $(20 \mathrm{ng} / \mathrm{mL})$, and HUVECs $\left(5 \times 10^{4}\right.$ cells/well $)$ were seeded into the upper chamber in serum-free media. The chamber was incubated at $37^{\circ} \mathrm{C}$ for $24 \mathrm{~h}$. Cells were then fixed with methanol, and stained with hematoxylin (Sigma, St Louis, MO, USA) and eosin (Sigma). Cells on the upper filter surface were removed, and migration was determined using a microscope, at $200 \times$ magnification, by counting cells that had migrated to the lower filter side. Samples were assayed twice, in triplicate.

\section{In vitro tube formation assay}

A 96-well plate was coated with Matrigel (10 mg/mL, BD Biosciences, San Diego, CA, USA), which was then allowed to polymerize for $1 \mathrm{~h}$ at $37^{\circ} \mathrm{C}$. HUVECs $\left(3 \times 10^{4}\right.$ cells $/$ well $)$ were seeded on the surface of the
Matrigel, with chemicals, in the presence of VEGF $(20 \mathrm{ng} / \mathrm{mL})$, at $37^{\circ} \mathrm{C}$ for $24 \mathrm{~h}$. Changes in cellular morphology were observed under a microscope and photographed at 100×.

\section{Chick embryo chorioallantoic membrane (CAM) assay}

Fertilized chicken eggs were maintained in a humidified incubator (Eunjo incubator company, Korea) at $37^{\circ} \mathrm{C}$ for three days. Chick eggshell membrane and $3-4 \mathrm{~mL}$ of egg albumin were removed from the egg. On Day 4.5, chemical-loaded Thermanox coverslips (NUNC, Rochester, NY, USA) were applied to the CAM surface. Two days later, $10 \%$ fat emulsion (Intralipid) was injected beneath the CAM and observed under a microscope. Retinoic acid (RA) was used as a positive control.

\section{Matrigel plug assay}

Matrigel (200 $\mu$ l, BD Biosciences) with DMSO, Compound $12(100 \mathrm{nM})$, and gefitinib $(5 \mu \mathrm{M})$ were inoculated subcutaneously into C57BL/6J mice. Matrigel plugs were removed at 10 days after inoculation and photographed. To quantitate the formation of functional blood vessel, the content of hemoglobin was measured using the Drakin's reagent kit (Sigma,).

\section{In vivo tumor allogaft experiment and immunohistochemistry}

LLC cells $\left(1 \times 10^{6}\right)$ were injected subcutaneously into the flanks of 6-week-old $\mathrm{C} 57 \mathrm{BL} / 6 \mathrm{~J}$ mice (Day 0)(SLC, Japan). Tumor size and body weight were measured 3 time a week. Tumor tissues were removed at day 20 after completion of injection of vehicle or drugs and fixed with $4 \%$ paraformaldehyde (PFA). After tissue processing for frozen sample preparation protocol, 
samples were embedded in OCT compound and frozen quickly by liquid nitrogen. Frozen blocks were cut into $10 \mu \mathrm{m}$ sections and stained with hematoxylin and eosin (H\&E) for light microscopy. Additional tissue sections for immunohistochemistry were blocked with 5\% goat serum in PBST $(0.03 \%$ Triton X-100 in PBS) and then incubated for $3 \mathrm{~h}$ at RT with following primary antibodies, anti-CD31 and anti-Ki67. To detect the hypoxic area in the tumors, Hypoxyprobe- $1^{\mathrm{TM}}$ (60 mg/kg, Natural Pharmacia International) was iv injected $90 \mathrm{~min}$ before tissue fixation. Tumors were harvested, sectioned and stained with FITCconjugated anti-Hypoxyprobe antibody.

\section{Statistical analysis}

All data were expressed as mean \pm standard deviations (SD) from at least 3 samples. Statistical comparisons were analyzed using the Student's $t$-test.

\section{ACKNOWLEDGMENTS}

This work was supported by NRF and KSEF grants funded by the Korean government (MSIP) (2012R1A4A1028835 and 2013R1A2A2A01068868).

\section{CONFLICT OF INTEREST}

The authors have no conflict of interest to declare.

\section{Authors' contributions}

K.H.P., H.E.L., S.H.L., D.H.L., T.L., Y.M.L. performed the experimental work and wrote manuscript; T.L. provided chemical libraries and discussion for the experimental data; Y.M.L designed the experimental plan, analyzed the data and wrote the manuscript.

\section{REFERENCES}

1. Bertout JA, Patel SA, Simon MC. The impact of $\mathrm{O} 2$ availability on human cancer. Nat Rev Cancer. 2008; 8:967-975.

2. Seok JK, Lee SH, Kim MJ, Lee YM. MicroRNA-382 induced by HIF-1alpha is an angiogenic miR targeting the tumor suppressor phosphatase and tensin homolog. Nucleic Acids Res. 42:8062-8072.

3. Mucaj V, Shay JE, Simon MC. Effects of hypoxia and HIFs on cancer metabolism. Int J Hematol. 95:464-470.

4. Lee SH, Kim J, Kim WH, Lee YM. Hypoxic silencing of tumor suppressor RUNX3 by histone modification in gastric cancer cells. Oncogene. 2009; 28:184-194.

5. Semenza GL. Targeting HIF-1 for cancer therapy. Nat Rev Cancer. 2003; 3:721-732.

6. Semenza GL. Oxygen sensing, hypoxia-inducible factors, and disease pathophysiology. Annu Rev Pathol. 9:47-71.
7. Rey S, Semenza GL. Hypoxia-inducible factor-1-dependent mechanisms of vascularization and vascular remodelling. Cardiovasc Res. 86:236-242.

8. Semenza GL. Hypoxia-inducible factors in physiology and medicine. Cell. 148:399-408.

9. Kim KH, Jung HJ, Kwon HJ. A new anti-angiogenic small molecule, G0811, inhibits angiogenesis via targeting hypoxia inducible factor (HIF)-1alpha signal transduction. Biochem Biophys Res Commun. 441:399-404.

10. Kim JH, Jang JW, Lee YS, Lee JW, Chi XZ, Li YH, Kim MK, Kim DM, Choi BS, Kim J, Kim HM, van Wijnen A, Park I, et al. RUNX family members are covalently modified and regulated by PIAS1-mediated sumoylation. Oncogenesis. 2014; 3:e101.

11. Ke Q, Costa M. Hypoxia-inducible factor-1 (HIF-1). Mol Pharmacol. 2006; 70:1469-1480.

12. Giaccia A, Siim BG, Johnson RS. HIF-1 as a target for drug development. Nat Rev Drug Discov. 2003; 2:803-811.

13. Pili R, Donehower RC. Is HIF-1 alpha a valid therapeutic target? J Natl Cancer Inst. 2003; 95:498-499.

14. Chen L, Endler A, Shibasaki F. Hypoxia and angiogenesis: regulation of hypoxia-inducible factors via novel binding factors. Exp Mol Med. 2009; 41:849-857.

15. Lee D, Kim D, Lee S, Kim T, Kim J, Kim S, Liu KH, Lee S, Bae JS, Song KS, Cho CW, Son YK, Baek DJ, et al. Efficient Syntheses of 1,2,3-Triazoloamide Derivatives Using Solid- and Solution-Phase Synthetic Approaches. Molecules. 2015; 20:19984-20013.

16. Lee T, Gong YD. Solid-phase parallel synthesis of druglike artificial 2H-benzopyran libraries. Molecules. 2012; 17:5467-5496.

17. Yeo EJ, Chun YS, Cho YS, Kim J, Lee JC, Kim MS, Park JW. YC-1: a potential anticancer drug targeting hypoxia-inducible factor 1. J Natl Cancer Inst. 2003; 95:516-525.

18. Rapisarda A, Uranchimeg B, Scudiero DA, Selby M, Sausville EA, Shoemaker RH, Melillo G. Identification of small molecule inhibitors of hypoxia-inducible factor 1 transcriptional activation pathway. Cancer Res. 2002; 62:4316-4324.

19. Kong D, Park EJ, Stephen AG, Calvani M, Cardellina JH, Monks A, Fisher RJ, Shoemaker RH, Melillo G. Echinomycin, a small-molecule inhibitor of hypoxia-inducible factor-1 DNA-binding activity. Cancer Res. 2005; 65:9047-9055.

20. Hodges TW, Hossain CF, Kim YP, Zhou YD, Nagle DG. Molecular-targeted antitumor agents: the Saururus cernuus dineolignans manassantin $\mathrm{B}$ and 4-O-demethylmanassantin $\mathrm{B}$ are potent inhibitors of hypoxia-activated HIF-1. J Nat Prod. 2004; 67:767-771.

21. Li SH, Shin DH, Chun YS, Lee MK, Kim MS, Park JW. A novel mode of action of YC-1 in HIF inhibition: stimulation of FIH-dependent p300 dissociation from HIF-1 \{alpha\}. Mol Cancer Ther. 2008; 7:3729-3738. 
22. Lee K, Kang JE, Park SK, Jin Y, Chung KS, Kim HM, Lee K, Kang MR, Lee MK, Song KB, Yang EG, Lee JJ, Won M. LW6, a novel HIF-1 inhibitor, promotes proteasomal degradation of HIF-1alpha via upregulation of VHL in a colon cancer cell line. Biochem Pharmacol. 2010; 80:982-989.

23. Befani CD, Vlachostergios PJ, Hatzidaki E, Patrikidou A, Bonanou S, Simos G, Papandreou CN, Liakos P. Bortezomib represses HIF-1alpha protein expression and nuclear accumulation by inhibiting both PI3K/Akt/TOR and MAPK pathways in prostate cancer cells. J Mol Med (Berl). 2012; 90:45-54.

24. Melstrom LG, Salabat MR, Ding XZ, Strouch MJ, Grippo PJ, Mirzoeva S, Pelling JC, Bentrem DJ. Apigenin down-regulates the hypoxia response genes: HIF-1alpha, GLUT-1, and VEGF in human pancreatic cancer cells. J Surg Res. 2011; 167:173-181.

25. Wang LH, Jiang XR, Yang JY, Bao XF, Chen JL, Liu X, Chen GL, Wu CF. SYP-5, a novel HIF-1 inhibitor, suppresses tumor cells invasion and angiogenesis. Eur J Pharmacol. 2016; 791:560-568.

26. Lee SH, Bae SC, Kim KW, Lee YM. RUNX3 inhibits hypoxia-inducible factor-1alpha protein stability by interacting with prolyl hydroxylases in gastric cancer cells. Oncogene. 33:1458-1467.

27. San Miguel JF, Schlag R, Khuageva NK, Dimopoulos MA, Shpilberg O, Kropff M, Spicka I, Petrucci MT, Palumbo A, Samoilova OS, Dmoszynska A, Abdulkadyrov KM, Delforge $\mathrm{M}$, et al. Persistent overall survival benefit and no increased risk of second malignancies with bortezomibmelphalan-prednisone versus melphalan-prednisone in patients with previously untreated multiple myeloma. Journal of clinical oncology. 2013; 31:448-455.

28. Tsai YP, Wu KJ. Hypoxia-regulated target genes implicated in tumor metastasis. J Biomed Sci. 19:102.

29. Folkman J. Role of angiogenesis in tumor growth and metastasis. Semin Oncol. 2002; 29:15-18.

30. Laughner E, Taghavi P, Chiles K, Mahon PC, Semenza GL. HER2 (neu) signaling increases the rate of hypoxiainducible factor 1alpha (HIF-1alpha) synthesis: novel mechanism for HIF-1-mediated vascular endothelial growth factor expression. Mol Cell Biol. 2001; 21:3995-4004.

31. Heeg S, Hirt N, Queisser A, Schmieg H, Thaler M, Kunert H, Quante M, Goessel G, von Werder A, Harder J, Beijersbergen R, Blum HE, Nakagawa $\mathrm{H}$, et al. EGFR overexpression induces activation of telomerase via PI3K/AKT-mediated phosphorylation and transcriptional regulation through Hifl-alpha in a cellular model of oralesophageal carcinogenesis. Cancer Sci. 2011; 102:351-360.

32. Chanmee T, Ontong P, Itano N. Hyaluronan: A modulator of the tumor microenvironment. Cancer Lett. 2016; 375:20-30.

33. Brown JM. Tumor microenvironment and the response to anticancer therapy. Cancer Biol Ther. 2002; 1:453-458.

34. Rankin EB, Giaccia AJ. Hypoxic control of metastasis. Science. 2016; 352:175-180.
35. Folkman J. Tumor angiogenesis: therapeutic implications. N Engl J Med. 1971; 285:1182-1186.

36. Ziemer LS, Koch CJ, Maity A, Magarelli DP, Horan AM, Evans SM. Hypoxia and VEGF mRNA expression in human tumors. Neoplasia. 2001; 3:500-508.

37. Carmeliet P, Jain RK. Angiogenesis in cancer and other diseases. Nature. 2000; 407:249-257.

38. Semenza GL. Intratumoral hypoxia, radiation resistance, and HIF-1. Cancer Cell. 2004; 5:405-406.

39. Jahangiri A, De Lay M, Miller LM, Carbonell WS, $\mathrm{Hu}$ YL, Lu K, Tom MW, Paquette J, Tokuyasu TA, Tsao S, Marshall R, Perry A, Bjorgan KM, et al. Gene expression profile identifies tyrosine kinase c-Met as a targetable mediator of antiangiogenic therapy resistance. Clin Cancer Res. 2013; 19:1773-1783.

40. Hartwich J, Orr WS, Ng CY, Spence Y, Morton C, Davidoff AM. HIF-1alpha activation mediates resistance to anti-angiogenic therapy in neuroblastoma xenografts. J Pediatr Surg. 2013; 48:39-46.

41. Semenza GL. Evaluation of HIF-1 inhibitors as anticancer agents. Drug Discov Today. 2007; 12:853-859.

42. Rapisarda A, Uranchimeg B, Sordet O, Pommier Y, Shoemaker RH, Melillo G. Topoisomerase I-mediated inhibition of hypoxia-inducible factor 1: mechanism and therapeutic implications. Cancer research. 2004; 64:1475-1482.

43. Welsh SJ, Williams RR, Birmingham A, Newman DJ, Kirkpatrick DL, Powis G. The thioredoxin redox inhibitors 1-methylpropyl 2-imidazolyl disulfide and pleurotin inhibit hypoxia-induced factor 1alpha and vascular endothelial growth factor formation. Mol Cancer Ther. 2003; 2:235-243.

44. Atkins MB, Larkin J. Immunotherapy Combined or Sequenced With Targeted Therapy in the Treatment of Solid Tumors: Current Perspectives. J Natl Cancer Inst. 2016; 108:djv414.

45. Lee SY, Oh SC. Changing strategies for target therapy in gastric cancer. World J Gastroenterol. 2016; 22:1179-1189.

46. Camidge DR, Pao W, Sequist LV. Acquired resistance to TKIs in solid tumours: learning from lung cancer. Nature reviews Clinical oncology. 2014; 11:473-481.

47. Cerniglia GJ, Pore N, Tsai JH, Schultz S, Mick R, Choe R, Xing X, Durduran T, Yodh AG, Evans SM, Koch CJ, Hahn SM, Quon H, et al. Epidermal growth factor receptor inhibition modulates the microenvironment by vascular normalization to improve chemotherapy and radiotherapy efficacy. PLoS One. 2009; 4:e6539.

48. Gong YD, Lee T. Combinatorial syntheses of fivemembered ring heterocycles using carbon disulfide and a solid support. J Comb Chem. 2010; 12:393-409.

49. Lee D, Lee S, Liu KH, Bae JS, Baek DJ, Lee T. Solid-Phase Synthesis of 1,3,7,8-Tetrasubstituted Xanthine Derivatives on Traceless Solid Support. ACS Comb Sci. 2016; 18:70-74. 